\title{
DIE NUWE-TESTAMENTIESE SKRIFOPENBARING OOR GODDELIKE UITVERKIESING
}

Prof. J. C. Coetzee

(Oorspronklik gelewer as 'n voordrag voor die Jaarvergadering van die landswye Gereformeerde Teologiese Vereniging, Pretoria, 9 Junie 1981).

\section{TER INLEIDING} word:

Enkele beperkinge ten opsigte van hierdie artikel moet gestel

Die skrywer is 'n Nuwe-Testamentikus en nie 'n dogmatikus nie en daarom word hier nie gepoog om 'n gesistematiseerde leer aangaande goddelike uitverkiesing aan te bied nie.

Die oogmerk is om alleen ernstig te vra: kom ons kyk saam nog 'n keer, en ook opnuut, indringend na 'n paar van die sleutelgedeeltes van die Skrif waar uitverkiesing of aspekte daarvan uitdruklik na vore kom. Geen aanspraak op volledigheid ten opsigte van die Skrifgedeeltes wat behandel word, word gemaak nie. Daar is inderdaad ander gedeeltes wat meerdere lig kan werp en meerdere aspekte na vore kan bring. Maar êrens moet ons begin om ons weer 'n keer af te vra wat sê die Skrif self oor wat sekerlik die hart van die Evangelie van Jesus Christus is.

Die sleutelgedeeltes wat wel bespreek word is

- Romeine 8:28-30, saam met die nou verwante 8:17;

- Efesiërs 1:3-14 (waarmee o.a. Ef. 3:8-12, $2 \mathrm{Tm} .1: 9$ en Tt. $1: 1-3$ sterk vergelykbaar is).

- Romeine 5:12-21, wat telkens na vore kom in diskussies rondom ,universele versoening" en/of ,universele aanbod van genade".

- 2 Petrus $3: 1-18$, bestudeer vanuit die crux interpretum naamlik vers 9 , wat ook skynbaar 'n universele verlossing leer.

- 2 Petrus $1: 3-11$, veral oor die verhouding van menslike verantwoordelikheid en goddelike roeping en uitverkiesing.

\section{GROOT VRAAGTEKENS OF LOFSINGENDE UITROEPTEKENS ?}

Dit val telkens weer op hoedat waar goddelike uitverkiesing (en verwerping) ter sprake kom, mense onmiddellik 'n klomp vraagtekens sien en self nog 'n paar daarnaas ophang. Die woord „uitverkiesing" is vir baie mense, ook selfs tussen Gereformeerde voorgangers, veelal sinoniem met 'n klomp probleme en moellike vrae wat ons menslike verstand treiter.

Hierin sit 'n ontsaglike stuk tragiek, want dit is JUIS NIE hoe die Woord van God oor die goddelike uitverkiesing praat nie. In radikale teenstelling tot ons baie vraagtekens, probleme en breingimnastiek hieroor, word oor goddelike uitverkiesing en oor die uitverkiesende God feitlik nooit anders gespreek nie as in LOFSINGENDE uitroeptekens, in verwonderde en aanbiddende lofsang nie. 
Enkele voorbeelde illustreer dié punt:

„Geseënd is die God en Vader van ons Here Jesus Christus wat ons geseën het met alle geestelike seëninge in die hemele in Christus, soos $\mathrm{Hy}$ ons in Hom uitverkies het voor die grondlegging van die Wêreld .... (Ef. $1: 3-4$ ).

„Wie kan beskuldiging inbring teen die uitverkorenes van God? God is dit wat regverdig mak! Wie kan veroordeel? Christus is dit wat gesterf het, ja meer nog, wat ook opgewek is, wat ook aan die regterhand van God is, wat ook vir ons intree!" (Rom. 8:33-34).

Vergelyk ook nog Rm. $8: 28-30$.

Dit is duidelik: die Skrif praat oor uitverkiesing steeds in die toon van dankbaar-blye, aanbiddend- verwonderde lofsange. En dit wil ook die gees en toon van hierdie artikel wees.

\section{2. 'N KORT OORSIG OOR DIE KERNVRAE RONDOM UITVERKIESING}

Sekere van die kernprobleme wat telkens weer rondom uitverkiesing, predestinasie, verwerping geopper word, word vervolgens kortliks gestel. Die skrywer wil dit duidelik stel dat onderstaande nie SY probleme in dié verband is nie, maar bloot 'n redelike weergawe probeer wees van die tipe vrae wat gedurig weer gevra word; ook dat daar geen pretensie is dat hierdie artikel antwoord gee of wil gee op al genoemde vrae nie.

2.1 Is daar inderdaad in die Bybel so ' $n$ leer en hoe ' $n$ belangrike plek neem dit in die Bybel in?

Daar is diegene wat in alle erns die vraag stel of daar hoegenaamd in die Skrif sprake is van predestinasie, uitverkiesing en verwerping. Indien wel, word gevra, lê dit nie maar op die heel randjie of periferie van die Evangelie nie, sodat mens daarmee nie juis eg erns hoef te maak nie; mens dit eintlik maar kan (of selfs mót) ignoreer, omdat dit ,'n harde leer" is wat mense van die Evangelie afskrik? Die lesers ken hierdie vrae en hoe hulle in baie kringe sowel die prediking as die geloofsdenke van mense kleur en beínvloed. Die skrywer gaan daar egter nle hier verder op in nie, aangesien aanvaar word dat ons saamstem dat ons onderwerp uit die Skrif self tot ons kom en nie op die periferie daarvan lê nie, maar Juis die hart van die Evangelie raak.

2.2 Wanneer vind die goddelike verkiesing plaas?

Is dit 'n uitverkiesing van ewigheid af wat onberouelik uitreik na die toekomstige ewige heil, dus ,van voor die grondlegging van die wêreld af" - soos ons dié uitdrukking telkens in die Bybel aantref. Of is dit ' $n$ uitverkiesing in die tyd, sodat ons liefs moet praat van die uitverkiesende God in die geskiedenis. Of is die een én die ander gelykelik waar en in volle harmonie met mekaar?. Hierdie vrae vorm die fokuspunte van die belangwekkende proefskrif van Harm Venema (1965. Uitverkiezen en Uitverkiezing in het Nieuwe Testament. Kampen. Kok) uit die „Vrijgemaakte” kringe.

2.3 Determinisme, of uitdrukking van Gods liefde?

Is uitverkiesing na God se vrye welbehae (Ef. 1:5), voorbeskikking tot voorwerpe van verderf en voorbeskikking tot voorwerpe van barmhartigheid ( $\mathrm{Rm}$. 9:22 en 23) nie koue determinisme of 
amper erger nog hardvogtige goddelike willekeur nie? Of is dit daarteenoor die uitdrukking van God se vrye en vrygewige, onbegryplike liefde in Christus?

In die woorde van Rm. $9: 19$ (1979 AV): „, Nou sal jy vir my sê Maar waarom verwyt Hy ons dan nog? Wie kan tog teen sy wil ingaan?"

2.4 Goddelike uitverkiesing en menslike verantwoordelikheid

Aan die anderkant, en wel in die woorde van die Heidelbergse Kategismus, vraag en antwoord 64: „mak hierdie leer" van God se ewige raad, met uitverkiesing en verwerping voor die grondlegging van die wêreld, nie inderdaad, ,goddelose en sorgelose mense nie?"

Die skrywer wil nie oordeel nie, hy vra alleen maar: hoe diep het die gees en denke van die sogenaamde Oud-Gereformeerde rigting ook by ons ingeslaan? En: tot hoe 'n mate dink en handel Gereformeerdes, nie net lidmate nie, maar ook leraars, in die volgende terme:

- Ek kan nie weet of ek uitverkies is nie, want dit is God se verborge raad;

- Daarom mag ons as Gereformeerdes ook nie juis praat van of preek oor persoonlike toeëiening van die heil nie;

- Ek kan self niks doen en hoef selfs ook niks te doen omtrent my saligheid nie - ek sit maar net en wag en niksdoen, want as ek uitverkies is, sal God my tog wel op sy bestemde tyd deur sy Gees roer en beweeg.

2.5 Het Christus vir alle mense gesterf, of net vir die uitverkorenes?

Wat wil Skrifuitsprake soos die volgende leer? Sommige sê:

hier het ons duidelik die leer van die algemene versoening. Tereg verwerp Gereformeerde teoloë dié siening. Maar waarom? Mag mens by onderaangehaalde tekste somaar .,van die uitverkorenes" bylees om dit baie Gereformeerd te laat klink? Ons mag immers nie méer gereformeerd wees as die Woord van God self nie!

Kom ons kyk wat daar staan.

Enersyds is daar Mt. 20:16: „Baie is geroep maar min is uitverkies."

Andersyds is daar die volgende getuienisse:

Rm. 5:19: "... so sal ook deur die gehoorsaamheid van die Een baie tot regverdiges gestel word."

$1 \mathrm{Tm}$. 2: 5, 6: „Daar is een God en een Middelaar tussen God en die mense, die mens Christus Jesus, wat Homself gegee het as 'n losprys vir almal."

Hb. 2:9: ".... sodat Hy deur die genade vir elkeen die dood sou smaak."

2 Pt. 3:9: „maar Hy is lankmoedig oor julle en wil nie hê dat sommige moet vergaan nie, maar dat almal tot bekering moet kom."

$1 \mathrm{Jh} .2: 2:$ "Hy is 'n versoening vir ons sondes, en nie alleen vir ons s'n nie, maar ook vir dié van die hele wêreld."

Die wesentlike vraag wat dikwels gevra word, is: Christus het tog duidelik die opdrag gegee om die Evangelie aan alle nasies en alle mense te gaan verkondig (Mt. 28:19). Maar as Hy net vir die 
uitverkorenes gesterf het, is die prediking aan alle mense dan nie tog maar leeg en eintlik bedrog nie?

Pregnant gestel: mag die prediker en die evangelisasie-werker of sendeling vir elke indiwidu sê: „Jesus het ook vir JoU gesterf glo dit en bekeer jou, en jy sal lewe!"

2.6 Hoe presies verkies God - bloot indiwidueel, persoonlik of korporatief?

Teenoor die drie of's hierbo gestel, stel ons die vraag of nie eerder van die uitverkiesing van God in die Skrif op verskillende vlakke sprake is nie?

Is dit nie byvoorbeeld moontlik dat van „uitverkiesing” op die volgende verskillende vlakke gepraat word nie:

(i) verkiesing van ' $n$ volk tot verbondsvolk;

(ii) verkiesing van 'n stamvader in wie die verbondslinie voortgesit word;

(iii) verkiesing tot 'n besondere diens - selfs sonder dat daarmee iets besluit is oor die persoonlike saligheid van daardie mens;

(iv) persoonlike verkiesing tot saligheid, en daarom tot diens van God nou en hier;

2.7 Is die leer van die volharding van die heiliges of uitverkorenes Bybelgetron of nie?

Alreeds vanaf die tyd van die Montaniste is die leer van die volharding van die heiliges en die onmoontlikheid van die uitval van uitverkorenes uit die genade bevraagteken. Hiervoor is veral 'n beroep op Hb. 6:4-6 gedoen. Of daarmee egter reg laat geskied is aan die skopus van hierdie verse is ernstig te betwyfel. Daarteenoor staan vele so klaarblyklik duidelike uitsprake, waaronder Jh. $6: 37,39,44,54$ en Jh. 10:27-29 seker die belangrikste is.

\section{3. 'N KURSORIESE ONTLEDING VAN ENKELE KERNBEGRIPPE}

\section{RAKENDE UITVERKIESING}

Hoewel uiteraard glad nie uitpunttend nie, word hier die kardinale betekenis van kembegrippe wat verband KAN hou met uitverkiesing kortliks bespreek.

3.1 Begrippe met 'n betekenisveld van: uitkies-verkies-kies

- Agapãn - Misein. Hierdie twee komplementêre werkwoorde het vanuit die Ou-Testamentiese agtergrond meermale - enigsins vreemd aan die Afrikaanse gevoelswaarde - 'n besliste "uitverkies" - konnotasie - soos duidelik te vinde is in Rm. 9:13.

- Eklegesthai - eklektos - eklogē

Ten opsigte van hierdie ooglopend belangrike woordgroep vir ons onderwerp moet ten minste vier gebruiksvlakke (of toepassingsvlakke) binne die betekenisveld van die woordgroep in die Nuwe Testament onderskei word:

3.1.1 Persoonlike verkiesing deur God/Christus tot 'n besondere diens:

(a) Jesus Christus, die Seun van God, is die Uitverkorene - Lk. 23 : 35: 1 Pt. 2 : 4.

(b) Mense, verkies tot ' $n$ besondere diens of amp:

- die twaalf apostels: Lk. $6: 13$; Hd. $1: 2$;

- Paulus: Hd. 9 : 15. 
Besonderlik belangrik is in hierdie verband $\mathrm{Jh} .13: 18$ gelees mede teen die agtergrond van Jh. $13: 11$ en Jh. 2:23-24.

Dit is bo alle twyfel duidelik dat dit hier nie gaan om 'n ewige uitverkiesing tot saligheid nie. Die egō oida tinas ekseleksamēn bedoel nie: „Ek weet wie Ek uitverkies het" nie (en dus ook: „wie Ek nie uitverkies het nie"), maar wel: „Ek ken (in hul harte die mense wat Ek (as dissipels) gekies het"-dus: Ek weet wat in Judas se hart omgaan.

3.1.2 „Korporatiewe" verkiesing as verbondsvolk

Telkens vind ons in die Nuwe Testament verkiesingsverwysings wat kennelik nie te make het met persoonlike uitverkiesing tot saligheid nie, maar met 'n „korporatiewe" verkiesing tot volk van God of tot plaaslike openbaring van die volk van God (of liggaam van Christus).

Sprekende voorbeelde is die volgende:

(a) Hd. 13:17: „Die God van hierdie volk Israel het ons vaders uitverkies...." - waar die ekseleksato kennelik dui op die verkiesing van Israel tot die Ou-Testamentiese verbondsvolk van God.

(b) 1 Pt. 2:9: „Maar julle is 'n uitverkore geslag, 'n koninklike priesterdom, 'n heilige volk...."-waar die ekleton duidelik heenwys na die Nuwe-Testamentiese kerk as die Godsvolk van die Nuwe Bedeling.

(c) $2 \mathrm{Jh}$. vers 1: „Die ouderling aan die uitverkore vrou en aan haar kinders...." - waar die elektēi na alle waarskynlik heid verwys na 'n plaaslike gemeente as volle openbaring van die bruid van Christus ter plaatse (vgl. ook $2 \mathrm{Jh}$. vers 13).

3.1.3. Persoonlike verkiesing ter voortsetting van die lyn van die verbondsvolk

Ook hier het „verkiesing" of „verwerping” en ander terme met dieselfde konnotasie (vgl. bo-aan 3.1) naamlik ,liefhê" en "haat" nie die betekenis - in elk geval beslis nie primêr nie - van: uitverkies tot persoonlike saligheid of „verwerp tot persoonlike verderf" nie.

Veral Rm. 9 en 11 is hier baie belangrik - hulle is immers kernhoofstukke in verband met die Bybelse uitverkiesingsleer. Rm. 9:6-13 met konsentrasie in $\mathrm{Rm} .9: 11$ het kennelik nie ' $n$ woord te sê oor persoonlike uitverkiesing tot saligheid nie, maar die kat' eklogèn vind sy skopus in die beskore wees tot dié een in wie God die lyn van die Ou-Testamentiese verbondsvolk hier en nou wil voortsit.

Dieselfde geld die uitspraak in Rm. 11:5 waar die kat' eklogen duidelik die voortsetting van die verbondsvolk in die Nuwe Bedeling aanbetref.

3.1.4 Persoonlike uitverkiesing tot ewige saligheid

Bo alle twyfel spreek die Nuwe Testament met die eklegesthaibegripsgroep ook, en besonderlik, oor die persoonlike uitverkiesing tot ewige saligheid.

Mt. $22: 14$ is duidelik: „Want baie is geroepenes, maar min is uitverkorenes (eklektoi)."

Ook Mt. 24: 22 en 24 spreek vir hulleself: 
„.... maar ter wille van die uitverkorenes (dia de tous eklek(höste, planēsai, ei dunaton, kai tous eklektous)."

tous) sal daardie dae verkort word."

Vergelyk ook veral Ef. 1:3-14 met spesiale verwysing na Ef. $1: 4$.

"....om, as dit moontlik was, ook die uitverkorenes te mislei

3.2 Begrippe met 'n betekenisveld van: God se raad - God se wil dit wat vir God aangenaam is.

- Boulomai - boulẽ - bouléma

- Thelein - thelèma

- Eudokia

- Mustērion

Boulomai - boulē - boulēma

Boulomai - dui sewe maal op God wat iets wil. Steeds gaan dit dan om God se wil, om gunstige geneigdheid in die geskiedenis. En tog, 2 Pt. 3:9 bly steeds 'n Skrifuitspraak in die geding: Sou ons hier 'n uitsondering kry in die gebruik van boulomai - sodat dit hier wel gaan om God se ewige raad? Hierop sal later teruggekom moet word.

Boule - is tradisioneel in die gereformeerde teologie by uitstek die woord vir God se ewige, onverbreekbare raad.

Venema $(1965,156-161)$ interpreteer boule radikaal as „Gods heilswil" in die geskiedenis. Hierin gaan hy te ver. Inderdaad mag boulē nie dogmaties oral eners verstaan word nie:

(i) In verskeie gevalle dui dit beslis op God se goeie wil, sy heilsryke begeerte in die geskiedenis, wat wel nie weerstaan MAG word nie, maar wat inderdaad weerstaan KAN word of gehoorsaam kan word.

Lk. $7: 30$ is 'n sprekende voorbeeld: „Maar die Fariseërs en die wetgeleerdes het die raad van God (tén boulèn tou theou) aangaande hulle verwerp deur hulle nie deur hom te laat doop nie." Hieruit blyk duidelik dat mens die voorkoms van boule versigtiglik en met groot noukeurigheid binne die bepaalde konteks moet interpreteer - anders kan mens in onmoontlike vaarwaters beland.

Soortgelyke voorbeelde is na alle waarskynlikheid Hd. 13:36 en Hd. $20: 27$.

(ii) Meermale egter dui boulë juis God se onverbreekbare wil of raad - veral tot heil - aan.

Die belangrikste enkele voorbeeld is Hb. 6:17: „Daarom het God, omdat Hy nog kragtiger aan die erfgename van die belofte die onveranderlikheid van sy raad (to ametatheton tés boulés auton) wou toon, dit met 'n eed gewaarborg....".

Vergelyk ook onder andere Hd. $4: 28$; Hd. 5:38-39; Ef. $1: 11$.

Boulēma - word in die Nuwe Testament net tweemaal gebruik, en daarvan net eenmaal, in Rm. 9:19, van God. Dáár dui dit op God se onverbreekbare raad: „Jy sal dan vir my sê: Waarom verwyt Hy dan nog, want wie het sy wil (boulèmati autou) weerstaan?" 3.3 Begrippe met ' $n$ betekenisveld: vooruit bestem - vooruit ken vooruit gereed maak.

Prohorizein; protithēmi-prothesis; proginōskein; proetoimazein; pro katabolēs kosmou. 
Ten opsigte van al hierdie begrippe probeer Venema (1965, veral 60-72) aanvoer dat hulle verwys na binne-tydse, binne-in die geskiedenis plaasvindende handelinge van God. In die geval van die uitdrukking pro katabolès kosmou (in Afrikaans steeds vertaal as: "voor die grondlegging van die wêreld") wil Venema die pro nie "tyds" verstaan nie, maar wel ruimtelik: „bo hierdie aardse uitgaande." Ridderbos (1966, Paulus. Ontwerp van zijn theologie. Kampen. Kok. 385-389) toon afdoende aan dat dit net nie kán nie.

Vervolgens word 'n heel bondige oorsig gegee oor die waarskynlike primêre betekenis van die Griekse uitdrukkings.

Prohorizein - dat God vir mense of sy skepping vooruit bepaal of vooruit bepaal of vooruit bestem - vergelyk veral Ef. 1:5 en $1: 11$ (vergelyk ook Bauer, 1958, 1406).

Protithēmi - in die medium gebruik: by sigself voorneem of vooruit besluit - vergelyk veral Ef. $1: 9$.

Prothesis - Goddelike voorneme, Goddelike besluit of raadsbesluit vergelyk veral Ef. $1: 11$.

Proginōskein en prognōsis: sowel die werkwoord as die selfstandige naamwoord beskryf NIE 'n onbetrokke ewige verstandswete nie, maar God se verbondsmatige vooruit-, of eerste, liefhê teenoor ons mense. Vergelyk vir die werkwoord veral $\mathrm{Rm}$. 8:29; Rm. $11: 2$ en $1 \mathrm{Pt}$. $1: 20$, en vir die selfstandige naamwoord veral $1 \mathrm{Pt} .1: 2$.

Pro katabolès kosmou - dit is 'n tegniese term vir: voor die skepping in die heel begin, en beteken: vanaf nog vóor die heel begin, of dan: van ewigheid af. In 'n enkele geval vind ons voorstel apo, maar sonder enige klaarblyklike betekenisverskuiwing.

Thelein - thelèma

In die Afrikaanse Vertaling is dit tradisioneel vertaal met „om te wil" en "wil".

Die woorde is die wydste terme vir enige daad, woord of gedagte wat God behaag, en wat uiting gee aan dit wat God van ons as mense/sy kinders wil hê.

God se thelèma MAG enersyds nie weerstaan word nie, maar KAN andersyds wel weerstaan word - tot eie verderf! Die sprekendste voorbeeld hiervan is Mt. 23:37 waar Hy met sy laaste besoek aan Jerusalem sê: „Jerusalem, Jerusalem, .... hoe dikwels wou Ek (ëthelèsa) jou kinders bymekaarmaak net soos 'n hen haar kuikens onder die vlerke bymekaarmaak, en julle wou nie (kai ouk èthelésate).

Hieruit is dit duidelik dat thelein-thelëma nie opsigself uitverkiesingsbegrippe is nie - en tog is dit behartigingswaardig hoedat thelèma in die hieronder te behandelde Efesiërs 1 driemaal in 'n intieme genitiefverbinding met kardinale uitverkiesingsbegrippe voorkom:

- hè eudokia ton thelématos autou

("die welbehae van sy wil") - vers 5 .

- to mustérion tou thelématos autou

(,die geopenbaarde misterie van sy wil") — vers 9 . 
- hē boulē touthelèmatos autou

( ,die raad - of besluit — van sy wil") — vers 11 .

Eudokia - hierdie is 'n kardinale begrip in die vasstelling van 'n Bybelgefundeerde uitverkiesingsleer. Dit is veral belangrik wanneer ' $n$ mens kom by 'n suiwere bepaling van die verhouding tussen uitverkiesing en verwerping.

Eudokia, wat in die Afrikaanse Vertaling deurgaans met „welbehae" vertaal word, word inderdaad in die Nuwe Testament in bonam partem, dit is met 'n goeie bedoeling, gebruik: dit dui dus God se welwillendheid, sy goeie bedoeling met ons aan.

Heeltemal ten onregte verklaar K. Schilder (Heidelbergse Categismus III, 430) soos vry aangehaal deur Venema $(1965,160-170)$ : ,dat de grond van iemands verdoemenis ligt in zijn onverzoende schuld, doch de grond van zijn verwerping in Gods welbehagen."

Venema (idem) stel dit mooi: ,....wordt in het N.T. de eudokıa Gods nimmer genoemd als grond van iemands verwerping. Eudokia is uiting van Gods liefde en verwerping is uiting van Gods toorn en een overgeven aan de straf vanwege eigen schuld." Ridderbos $(1966,390)$ sê ook: ,.... Gods eudokia, een begrip, dat zowel het element van het goedgunstige als van het vrije omvat" (Ridderbos se beklemtoning). Die oordeel oor of die verwerping van die goddelose is nooit KATA EUDOKIAN d.i. volgens, of in ooreenstemming met, God se goeie bedoeling" met mense nie!

Mustérion - ook hierdie woord kom in die Nuwe Testament telkens voor. Dit beskryf God se ewige besluite na hulle vroeëre verborge karakter, maar wat NOU in God se heilsplan in en deur sy Seun Jesus Christus so wonderbaarlik geopenbaar is.

3.4 Begrippe met die betekenisveld van: God roep - deur God geroep word (of wees)

- Kalein - klésis - klētos

Hierdie woorde staan in die Nuwe Testament herhaaldelik in die nouste verband met uitverkiesingsterminologie. Vergelyk onder andere Rm. $1: 7$; Rm. 8:28-30; 2 Pt. 1:3, 10; Op. $17: 14$ ).

God se ROEPING is in die Nuwe Testament steeds: die konkretisering van die ewige uitverkiesing, hier en nou, aan die uitverkorenes, en wel heel persoonlik.

"Roeping" is in die Skrif, negatief gestel, nooit (in ons kerklike sin van die woord) "GAAN, en verrig hierdie of daardie taak" nie; maar, positief gestel, wel altyd: „KOM - Ek ken jou vooruit - kom dan nou ook na My toe in ware geloof." (Vergelyk die bespreking van 2 Pt. $1: 3-11$ hieronder).

„Roeping" in Nuwe-Testamentiese sin is: die konkrete, heilryke verklaring van God se kant dat Hy my sy uitverkore kind noem en dat Hy daarom toeroep om na Hom te kom en metterdaad te leef as sy uitverkore kind.

\section{4. 'N ONTLEDING VAN ENKELE BASIESE NUWE-TESTAMENTIESE GEDEELTES}

In aansluiting by die inleiding word duidelikheidshalwe gestel: Die doel van hierdie gedeelte van die artikel is NIE om 'n afgeronde 
en volledige antwoord rondom sekere vrae rakende die uitverkiesing te gee nie.

Daarom word ook nie 'n uitgebreide beredenering aangebied nie. Die doel is om vanuit die gesigshoek van die Nuwe-Testamentiese eksegese en hermeneuse aan te toon hoedat die gebruikmaking van gesonde huidige eksegetiese metodes fris en helder lig kan laat val op sekere „moeilike” Skrifgedeeltes wat ons onderwerp raak.

\subsection{Romeine $8: 28-30$}

Ons het hier 'n kardinale ,uitverkiesings"- of „predestinasie"uitspraak. Die Dortse Leerreëls (Hf. 1, Verwerping, par. 2) praat pragtig van die "goue ketting van ons saligheid".

Die hoofskakels van hierdie ketting is kennelik:

Ewige verkiesing - roeping hier in die tyd - versekerde eindbestemming.

Tog is juis hier praggedeeltes telkens weer - veral vanweë die Afrikaanse (en ander) vertalings - aanleiding gewees tot die gevaar van ' $n$ byna fatalistiese of pragmatisties-deterministiese interpretasie van die predestinasieleer. Die sleutelwoorde is hierdie uitspraak van Rm. 8: 28:

\section{panta sunergei eis agathon}

Die tradisionele Afrikaanse verklaring lui ,dat vir hulle wat (vir) God liefhet, alles ten goede meewerk."

So vertaald, sê die teks vir elke denkende leser: Elke ding wat met jou gebeur - as jy maar 'n liefhebber van God is - werk vir jou mee tot een of ander (hoewel onberekenbare) goeie einde.

Dus: moet jou nie bekommer nie, of jy dit nou sien of verstaan of nie, iets goeds sal voortkom uit die kwaad wat jou vandag of môre tref.

Dit het m.i. die dodelike gevaar ingehou van 'n deterministiese, fatalistiese „predestinasie"-beskouing dat alles, letterlik ALLES, in jou lewe - ook jou eie kwade dade! - een of ander ,goed"(?) tot gevolg sal moet hé!

'n Verantwoorde, indringende ANALISE van die GEDAGTESTRUKTUUR van Rm. 8:8-30 (gestut deur die sintaktiese struktuuranalise van Van Rensburg, J. J. 1980, Die ontleding van sintaktiese struktuur. Die ontwerp van 'n metode, geillustreer met Romeine 8. Potchefstroom. PU vir CHO. 1940-141) toon ons insiens die totale onhoudbaarheid van so'n fatalisties-predestinasistiese verstaan van $R m .8: 28-20$.

Die kernvraag rakende hierdie sentrale perikoop is: wat beteken die woorde panta sunergei eis agathon?

Vergelyk hiervoor onderstaande gedagtestruktuurontleding: 
In die Skriflig 29

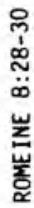

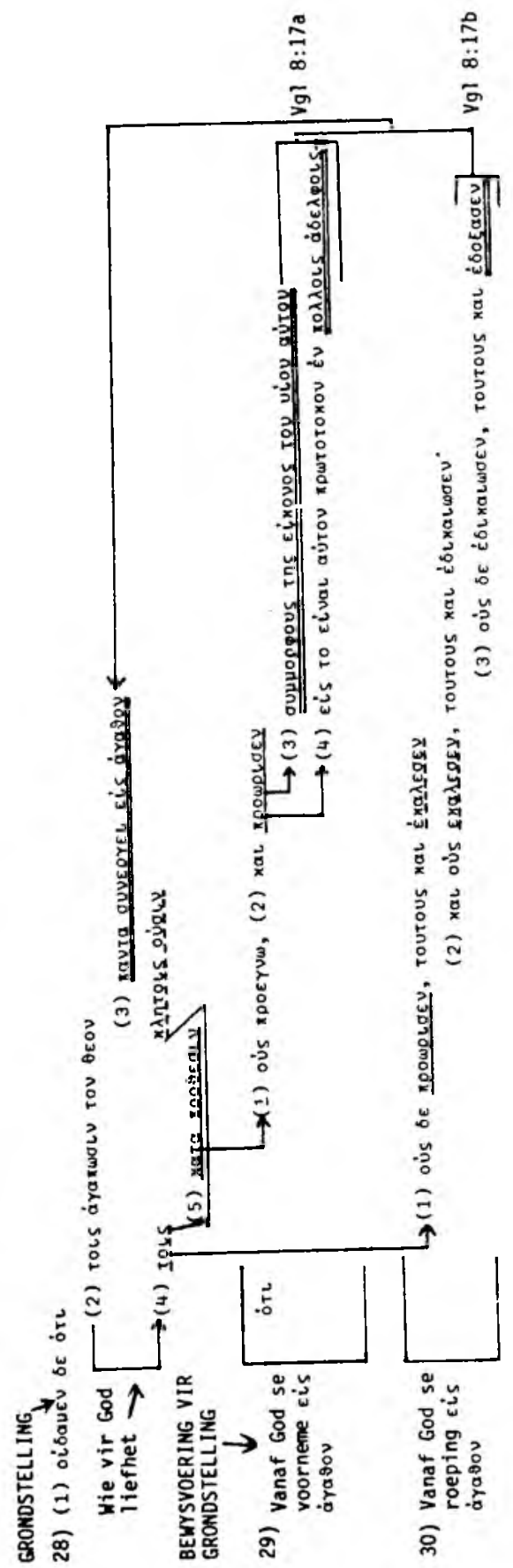




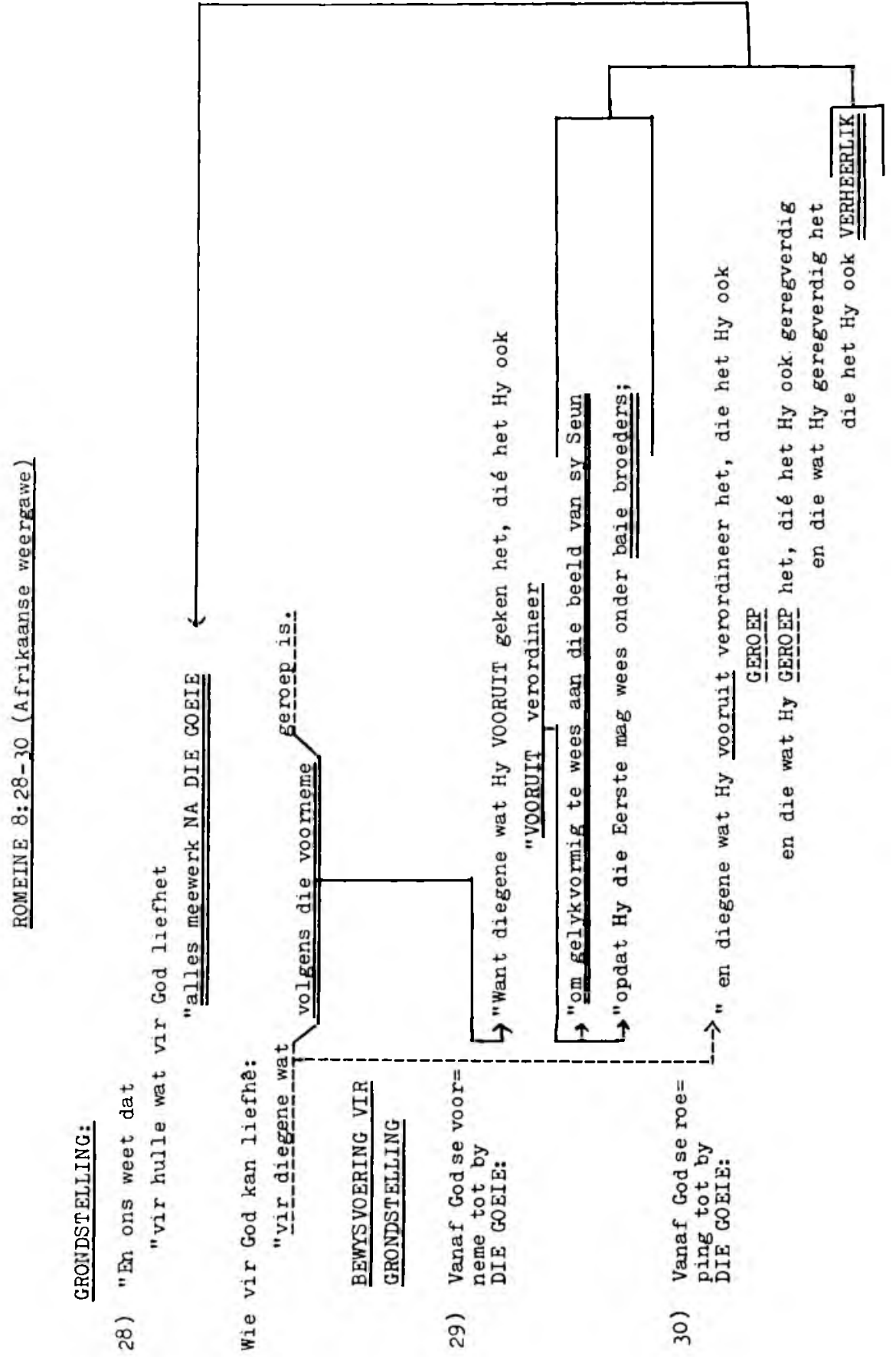


Uit bostaande gedagtestruktuuranalise is éen saak bo alle twyfel duidelik.

Oie eis agathon MAG NIE fatalisties-deterministies verstaan word as sou die Skrif ons leer dat elke „toevallige" ding in ons lewe tóg op die ou einde ,iets goed" meebring nie - inteendeel!

Wat dit wel wil sê is dat deur God se ewige, uitverkiesende genade ALLES in die lewe van sy uitverkorenes heenwerk na DIE GOEIE, d.i. na God se ewige BELOOFDE EINDDOEL met sy uitverkore kinders.

Dus: verre daarvan dat Paulus sou wou sê dat elke gebeurtenis in ons lewe tog wel een of ander, onbepaalbare, ,iets goeds" as doel het, sê hy: vir dié wat vir God liefhet, werk alles, voorspoed én teëspoed, heen na DIE GOEIE, dit wil sê, na God se gróót einddoel met sy kinders $(8: 17)$, na: die gelykvormigwording aan die beeld van sy Seun" ( $8: 29)$ en dus aan: „die verheerliking” $(8: 30)$. So word ons sungklēronomoi, mede-erfgename met Christus aan die „Ewige Goed"! (Vergelyk 8:17).

Só kry die uitverkiesingsprediking van $\mathrm{Rm}$. 8, in plaas van 'n ingelese deterministiese ,alles in ons lewe het tog een of ander goeie iets ten doel", 'n heerlike eskatologies-profetiese betekenis: alles - ook bittere lyde - in jou lewe lei na God se messiaanseksatologiese einddoel met jou: dat $j y$, gelykvormig aan die beeld van sy Seun, en dus verheerlikte, mede-erfgenaam van die ewige heerlikheid sal wees $(8: 29 \mathrm{~b} ; 8: 30 \mathrm{c}$ en $8: 17)$.

' $n$ Vergelykende diagram van $\mathrm{Rm} 8: 17$ en $\mathrm{Rm} 8: 29 \mathrm{~b}$ en $30 \mathrm{C}$, is insiggewend: Die verband tussen $\mathrm{Rm}$ 8:17 en $\mathrm{Rm}$ 8:28-30.

Rm 8:17:

(a) Ei $\delta \varepsilon$ тєหน xal xinpovousc

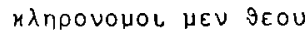

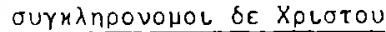

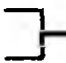

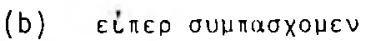

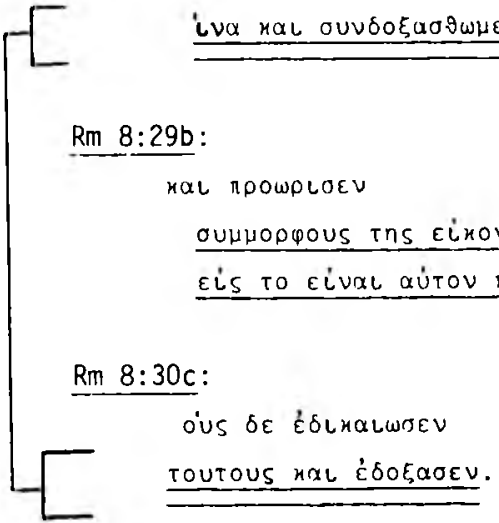


4.2 Efesiërs $1: 3-14$.

Efesiërs $1: 3-14$ is bo alle twyfel die locus classicus rakende die Bybelse uitverkiesingsleer.

Ons wil daarom volstaan deur in hierdie artikel hierdie sleutelgedeelte behoorlik te analiseer, sekere kernmomente uit te lig en dit dan aan die lesers deur te gee vir nadere interpretasie en konkrete toepassing.

Ons begin met 'n breë, oorsigtelike analise wat dan in sekere, meer toegespitste onderdele belig word:

Eresitris $1: 3-14$

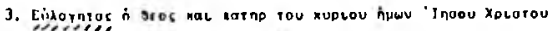

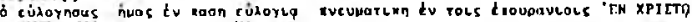

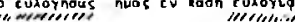

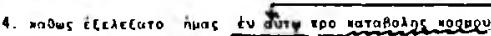

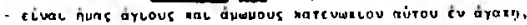

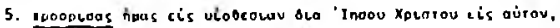

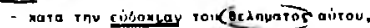

6. - Eis craluov solns ins frapltos pairou

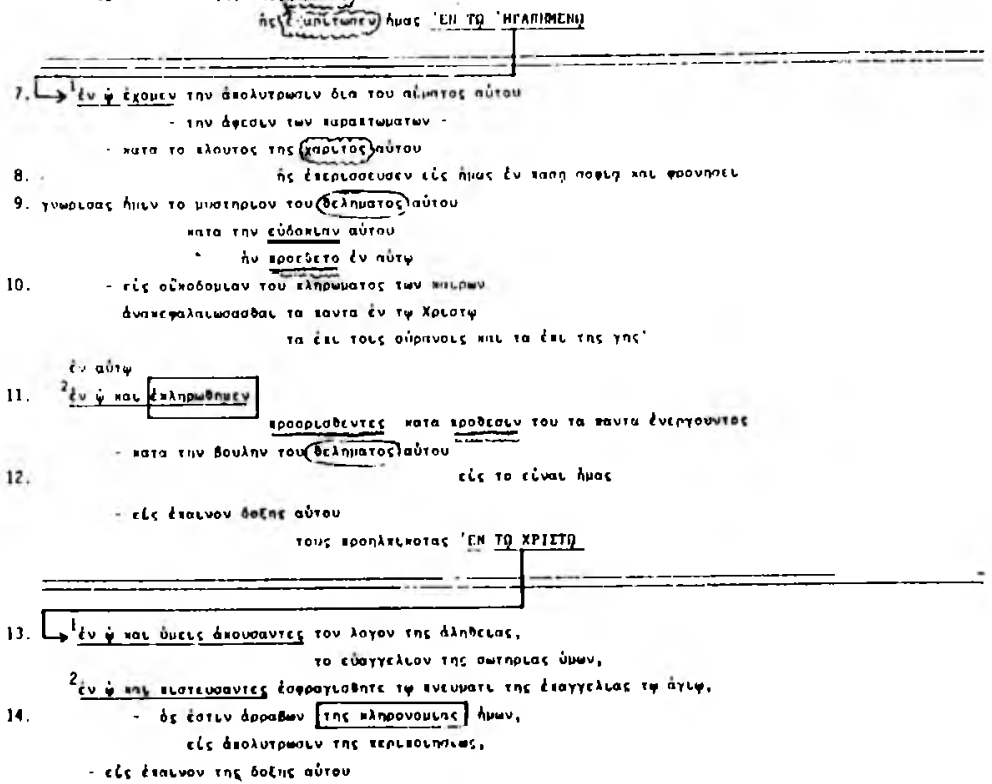


Die voorafgaande ontleding van die gedagtestruktuur van Er. $1: 3-14$ toon sekere baie opvallende trekke wat vir die verstaan van die Bybelse uitverkiesingsleer baie belangrik is:

(i) Dit toon die besonder fyn strukturering van hierdie perikoop, wat dit 'n besliste poëtiese karakter gee - Paulus kan en wil alleen maar SING oor die wonder van God se verkiesende liefde.

(ii) Opvallend is die herhaalde voorkoms van pro-woorde (voorwoorde) in verse 4,5,9 en 11 (tweemaal). Die "vooruit-karakter" van die verkiesing word dus sterk onderstreep.

(iii) Deur 'n heel besondere strukturering word benadruk dat die ewige uitverkieseing geen koue, apatiese en/of deterministiese of willekeurige daad van God was nie, maar 'n integrale deel, miskein nog liewer die sentrum van die openbaring van sy ondeurgrondelike liefde in en deur die koms van die Seun van God as Jesus die Christus hier in die geskiedenis is.

UITVERKIESING IS VOLUIT 'N CHRISTOLOGIESE DAAD GODS!

Die volgende uittreksel uit die bostaande struktuurananlise illustreer dit baie duidelik:

Ef. 1 : 3-14: Uitverkiesing as Christologiese daad Gods

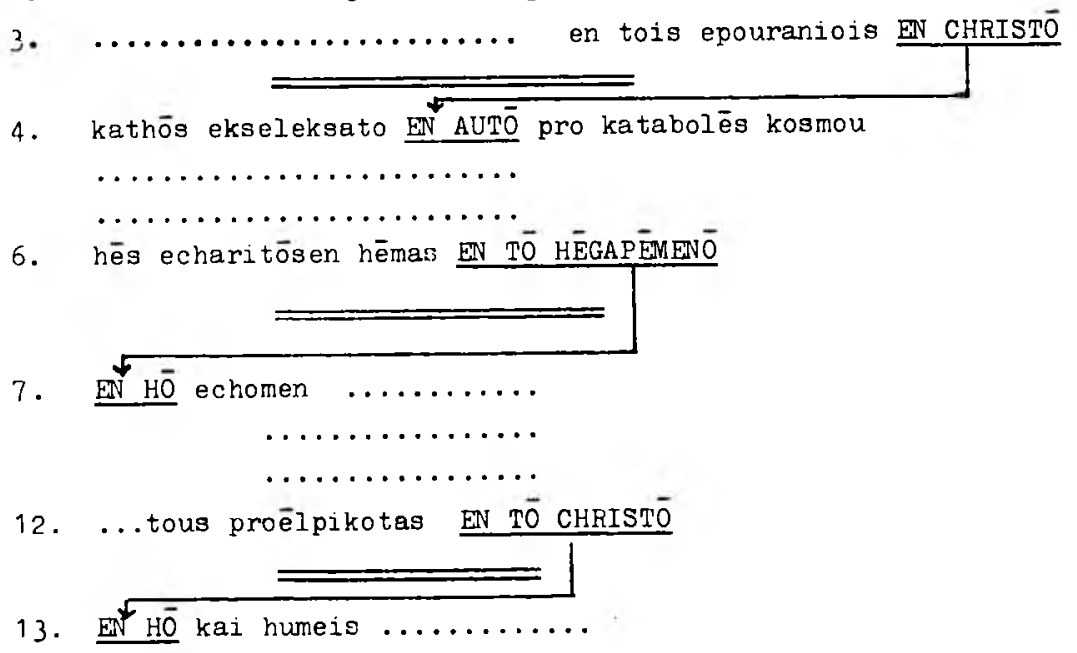

Die bedoeling van die besondere strukturering is baie duidelik: Elke kleinere gedagte-eenheid sluit met 'n Christologiese titel wat Christus beklemtoon as die Een in of deur Wie God uitverkiesend handel, en elke nuwe kleinere gedagte-eenheid neem dit onmiddellik weer op met 'n en+datief van die agent deur wie die handeling geskied. Dit word driemaal herhaal - die Joodse getal van volheid. Op die mees benadrukte wyse wil Paulus dus sê: UITVERKIESING IS VOLUIT 'N LIEFDEVOLLE CHRISTOLOGIESE DAAD GODS ! 
(iv) Uit die voorafgaande struktuuranalise blyk ook duidelik wat God se „maatstaf" of „rigsnoer" by sy verkiesing was. Weer volg 'n uittreksel uit die volledige analise om dit te illustreer:

Ef. 1:3-14: God se MAATSTAF by sy verkiesing

5. kata tēn eudokian tou thelēmatos autou - volgens die welbehae van sy wil -

9. kata tēn eudokian autou

- volgens sy welbehae -

11. kata tēn boulēen tou thelèmatos autou

- volgens die raad van sy wil -

Deur ' $n$ baie opvallende herhalingspatroon, weereens in die driemalige volheidspatroon, benadruk Paulus die absoluut soewereine, vrye, maar tegelyk welwillende (vergelyk die vroeë bespreking van eudokia en theléma), maatstaf van God by die uitverkiesing.

(v) Laastens wil ek wys op die duidelike herhalingspatroon wat die direkte en die finale DOEL van God met sy uitverkiesing volgens Ef. $1: 3-14$ benadruk:

Ef. 1:3-14: God se DOEL met sy uitverkiesing

3. Eulogetos ho theos

- Geprese is God -

4.

einai hēmas hagious kai amōmous katenōpion autou en agapẽ - opdat ons heilig en sonder gebrek voor Hom kan wees in liefde -

6. eis epainon doksēs tēs charitos autou....

- tot lof van die heerlikheid van sy genade -

12. eis epainon tès doksēs autou, tous proèlpikotas....

- (sodat ons sal wees) tot lof van sy heerlikheid, ons wat vooruit gehoop het....-

14. eis epainon tēs doksēs autou

- tot lof van sy heerlikheid -

Opvallend uit bostaande is die volgende:

(i) As doel van God se uitverkiesing kom ons ewige saligheid hier glad nie in die gesigveld nie. Dit is eerder die wonderlike gevolg van die uitverkiesing.

(ii) Die direkte of eerste doel word vooraf een maal in vers 3 genoem: die hier-en-nou doel dat God se uitverkorenes "heilig en sonder gebrek" voor God sal lewe, en dan wel "in liefde" in antwoord op sy wonderlike uitverkiesende liefde. Die uitverkiesing het dus PRIMER ten doel dat die uitverkorenes hier op aarde sal lewe in diens van, en na die beeld van God.

(iii) Die einddoel van die uitverkiesing word weereens in die opvallende drie maal herhaalde struktuurpatroon beklemtoon: „tot lof 
van sy heerlikheid," d.i. sodat $\mathrm{Hy}$ in sy heerlikheid alle lof sal ontvang: Soli Deo Gloria.

4.3 Romeine $5: 12-21$ en 2 Petrus $3: 1-10$ (besien vanuit $3: 9$ )

Hierdie twee Skrifgedeeltes kom telkens weer in die gedrang wanneer dit gaan om die vrae rondom uitverkiesing en versoening - saamgetrek in die pregnante vraag: Het Jesus Christus aan die kruis vir alle mense gesterf?

Weereens, dit is nie die bedoeling van hierdie artikel om hieroor dogmatiese of apodiktiese antwoorde te gee nie. Natuurlik spreek die Gereformeerde Belydenisskrifte hulle baie duidelik uit teen enige vorm van 'n universele versoeningsleer, of anders gestel teen enige gedagte dat op die ou einde alle mense tog maar salig sal word. Hiermee stem die skrywer onvoorwaardelik saam. Die Skrif laat hieroor GEEN twyfel nie.

Dit is nie ' $n$ vraag wat hier in diskussie is nie. Dit is 'n saak wat vir géén Gereformeerde wat die belydenis omhels omdat dit in ooreenstemming met die Skrif is, 'n punt van diskussie mag wees nie.

Wat WEL in diskussie is en moet wees, is die vraag: mag of durf ons sê: Jesus se versoeningsdood aan die kruis was 'n betaling net vir die sondes van die uitverkorenes? Of dan negatief gestel:

Jesus het nie gesterf vir die sonde van diegene wat verlore gaan nie? Nog anders gesê: Sou iemand voor die regterstoel van Christus kan verskyn en homself verdedig met die argument: Here, ek gaan verlore omdat $U$ nie genoeg gedoen het om ook mý sonde te versoen nie?

Ten opsigte van hierdie vrae word die korrekte interpretasie van Romeine $5: 12-21$ en Petrus $3: 1-11$ baie belangrik.

\subsubsection{Romeine $5: 12-21$}

Hier word eerste gelet op die struktuur van Romeine $5: 12-21$.

Die parallellisme tussen "die een" en "die almal" en "die een" en "die baie."

12.

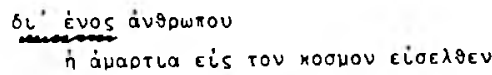

หal ola ths áfaptlas ó gavaros,

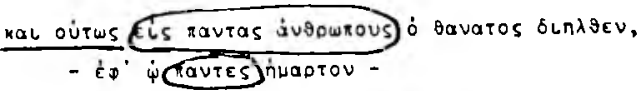

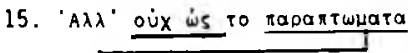

outws Hal to xaplona

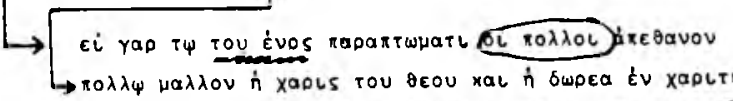

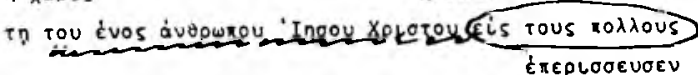


18. 'A oùv

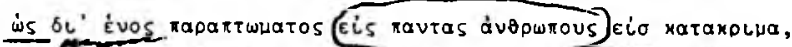

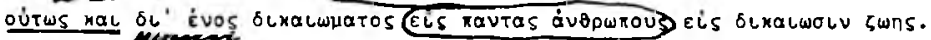

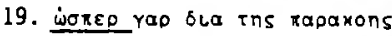

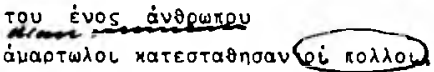

oùws xal ola ths üraxons tou Ėvos

GLหaL

Uit bogenoemde struktuuranalise blyk die volgende duidelik:

(i) Daar is 'n volslae, selfs 'n rigoristiese parallellisme, tussen enersyds "die een - die almal" en "die een - die baie."

(ii) Teenoor „die een", hetsy Adam of Christus, staan afwisselend en ook volledig parallellisties "die almal" en "die baie".

(iii) Hieruit is volledig duidelik dat "pantes" ("die almal") en "hoi polloi") nie anders verstaan kan word dan as volledige sinonieme nie.

(iv) Die feit dat die genade in Jesus Christus vir "die baie" is (5:15), en dat ,deur die gehoorsaamheid van die Een hoi polloi, (die baie) tot regverdiges gestel word", mag dus hoegenaamd nie in uitverkiesingskategorieë geinterpreteer word nie, as sou Paulus hier wou sê dat Jesus se soendood net betekenis het vir "die baie" in die sin van "nie almal nie, maar net vir die uitverkorenes."

(v) Indien die interpretasie wat in (iv) afgewys is, gehandhaaf sou word, sou dit mens - vanweë die sterk parallellistiese opbou van hierdie gedeelte - in 'n absoluut onhoudbare posisie plaas: sou die hoi polloi of "die baie" ten opsigte van Christus se reddende soendood net op die uitverkorenes, en nie op alle mense nie, slaan, dan sou dit $66 \mathrm{k}$ beteken dat die hoi polloi of "die baie" van $5: 15 \mathrm{~b}$ (,want as deur die misdaad van die één hoi polloi-die baie - gesterf het") en die hoi polloi of "die baie" van vers 19a (,want soos deur die ongehoorsaamheid van die een mens hoi polloi-die baie - tot sondaars gestel is") net op sekere mense, die verworpenes, moet slaan. En tog, ons weet bo twyfel: alle mense het deur Adam sondaars geword en onder die skadu van die ewige dood gekom! Net so min as wat die sonde van „die een". d.i. Adam, net trefkrag het vir die sonde en die dood van „baie, maar nie alle" mense nie, net so min het die soendood van Jesus Christus net trefkrag vir „baie, maar nie alle” mense. Maar: terwyl die sonde van die een, d.i. Adam, effektief die dood van alle mense meegebring het, omdat almal deel het aan die sonde van Adam, het slegs die uitverkorenes effektief deel aan die universeel genoegsame soendood van die Een, nl. Christus, omdat 'n mens slegs deur die geloof daaraan effektief deel kan kry.

4.3.2 2 Petrus 3:1-10-Universele heil?

2 Petrus $3: 9$ is tradisioneel ' $n$ ware crux interpretum, 'n interpretasieprobleem. 
Dit lui: „Die Here vertraag nie die belofte, soos sommige dit vertraging ag nie, maar $\mathrm{Hy}$ is lankmoedig oor julle, en wil nie hê dat sommige verlore moet gaan nie maar dat almal tot bekering moet kom."

Die kardinale vraag is hier: predik Paulus hier inderdaad 'n universele verlossingsleer? Sê hy: op die ou einde wil God volgens sy ewige, beslissende raad tóg nie hê dat enigiemand verlore gaan nie, maar het Hy van ewigheid af beslis dát almal gered sál word?

Om aan hierdie skynbaar-logiese konsekwensie te ontkom het gereformeerd-gesinde eksegete telkens weer verskeie eksegetiese spronge met dié Skrifgedeelte probeer maak: na die „julle" of, volgens die tradisionele maar swakker lesing, na die "ons" sou dan of 'n „dit wil sê die uitverkorenes" of 'n "dit wil sế die lede van die kerk van Christus" verstaan moet word. Dit is klinkklaar duidelik inlegkunde - dit staan, nóg eksplisiet nóg implisiet net eenvoudig nie daar nie. Dit is summiere „dogmatistiese" eksegese wat onverdedigbaar is.

Die antwoord lê daarteenoor myns insiens in 'n eerlike en deeglike eksegese van die hele KONTEKS waarbinne hierdie kernuitspraak voorkom.

Daarom volg hier nou 'n kursoriese analise van die gedagtestruktuur van 2 Pt. $3: 1-10$.

\begin{tabular}{lll}
\hline Eenhede & Aard & Inhoud \\
\hline
\end{tabular}

1.

3:1-2 Doel en karakter 'n Herinneringsbrief en -gedeelte.

Skerp herinnering met die oog op die gelo. wiges se helder-oordelende lewensbenade. ring (eilikrine dianoian).

\begin{tabular}{|c|c|c|c|}
\hline $2.3: 3-4$ & $\begin{array}{l}\text { Skynbaar gegronde } \\
\text { SPOT } \\
\text { van die goddelose }\end{array}$ & $\begin{array}{l}2.1 \\
2.2\end{array}$ & $\begin{array}{c}\text { Die SPOT self: Die wederkoms realiseer } \\
\text { TOG nie! }(3: 3-4(a)) \\
\text { Die ARGUMENT van die spotters: }\end{array}$ \\
\hline $3: 5-10$ & $\begin{array}{l}\text { OPENBARINGS- } \\
\text { ANTWOORD } \\
\text { deur herinnering }\end{array}$ & 3.1 & $\begin{array}{l}\text { Herinnering aan DIE SONDVLOED - } \\
3: 5-7 \\
\text { Verwysing na: DIE TORA! } \\
\text { Alles bly dus nie maar dieselfde nie. } \\
\text { God, die Skepper, het reeds eenmaal } \\
\text { gekom in gerig deur water. Ons weet } \\
\text { dus seker Hy sal weer kom in gerig } \\
\text { met vuur! } \\
\text { (Herinnering aan Gn } 1: 6-9 \text { en } 7: \\
\text { 11-21). }\end{array}$ \\
\hline
\end{tabular}

3.2 Herinnering aan DIE LIED VAN MOSES

$-3: 8$

Verwysing na DIE CHETOEBIM.

Die spotters insinueer dit duur al so lank dat dle wederkoms ultbly. Maar onthou: God se tyd is nie ons tyd nie! (Herinnering aan Ps. $90: 4$ ).

3.3 Herinnering aan? $-3: 9$.

3.4 Herinnering aan die HERE JESUS SELF EN AAN DIE APOSTEL PAULUS 3: 10 
Verwysing na: JESUS en die APOSTELS

- Al bly die wederkoms lank uit, ons mag nie verslap en inslaap nie. Onthou hoe die Here self gesê het: Die dag van die Here sal kom soos 'n dief in die nag. (Herinnering aan Mt. $24: 43-44$, Lk. 12 : $39-40$ en 1 Th $5: 2-4$ ).

GEVOLGTREKKINGS UIT BOSTAANDE ANALISE:

(i) Dit is duidelik dat sowel 'n simplistiese afleiding van 'n leer van universalistiese eind-verlossing as 'n gedwonge ,uitverkiesings" -interpretasie van 2 Pt. 3 : 9 geheel en al buite die skopus van die konteks val.

(ii) Petrus verklaar nadruklik dat hy nie - ook nie in 3:9 nie iets nuuts wil sê nie. Hy wil doelbewus net ,deur herinnering" by sy lesers 'n ware "helder-oordelende lewensbenadering" opwek.

(iii) Sy hele beredenering behels daarom - voorlopig met uitsluiting van 3:9-herinnerende verwysings na Godswoorde uit die verskillende dele van die Ou- en Nuwe-Testamentiese Godsopenbaring:

(a) Uit die Tora $-3: 5-7$;

(b) Uit die Chetoebim $-3: 8$;

(c) - ?

(d) Uit die woorde van Jesus en die Apostels.

- Wat bly dus in gebreke?

Natuurlik - 'n herinnerende verwysing na God se Woord deur die profete.

(iv) En dan val onmiskenbaar in die oog die duidelike, oor-en-oor herhaalde getuienis van die voor-ballingskapse profete, veral Esegiël, dat die Here, hier in dié tyd en binne die konkrete historiese situasie geen behae het in (plat gestel: geen plesier skep uit) die dood van die sondaar(s) nie, maar dat Hy begeer dat hy (hulle) hom (hulle) bekeer - en lewe. Dárom, sê Petrus, is Hy so lank van geduld met julle (d.i. met die mensdom).

(Herinnering aan o.a. Es. $18: 23,32$ en veral Es. $33: 11$ ).

(v) Saamgevat: die uitspraak van $2 \mathrm{Pt}$. 3:9 het, in die lig van die breëre konteks, niks te make met 'n "nuut-uitspraak" oor universele heil al dan nie. Die uitspraak val geheel en al "deur herinnering" aan wat al by wyse van Godsprake geopenbaar is, te antwoord op die spottersvraag waarom Jesus dan nog nie weer gekom het nie.

Aldus wil 2 Pt. 3:9 die bepaalde terrein van die Godsopenbaring oor God se heil-en-gerig-plan dek: Waar 3:5-7 die Tora kwoteer; $3: 8$ die Chetoebim en $3: 10$ Jesus en die Apostels, daar het $3: 9$ ten doel om vanuit die profete te toon waarom die wederkoms nog nie plaasgevind het nie.

Die uitsluitlike antwoord van $3: 9$, teen die agtergrond van die profete (veral Esegiël - vergelyk genoemde tekste) is nie God se ewige, „onverbiddelike", raad nie, maar God se goeie wil, dit wat Hom vreugde verskaf of nie. Konkreet: dit is vir God géén vreugde 
of plesier dat sondaars verlore gaan nie. Sy vreugde en plesier is daarin dat hulle hul bekeer - en LEWE!

4.3.3 2 Pt. $1: 3-11$-Die verhouding van menslike verantwoordelikheid en Goddelike roeping en uitverkiesing

Weereens is die bedoeling nie om 'n dogmaties - allermins 'n dogmatistiese - oplossing te gee nie. Die uitsluitlike bedoeling is om die mees relevante Nuwe-Testamentiese gegewens direk aan die orde te stel, en enkele peilers daaruit te identifiseer.

$\mathrm{Na}$ die mening van die skrywer is $2 \mathrm{Pt}$. 1:3-11 hier absoluut primêre materiaal. Die fokuspunt van hierdie perikoop is ongetwyfeld vers 10: „Daarom destemeer, broeders, beywer julle om julle roeping en verkiesing vas te maak." Dat vers 10 die fokuspunt of kernvers van die perikoop is, onderstreep Petrus met die buitengewoon sterk beklemtoning van "dio mallon, adelfoi, spoudasate": (i) die aanspreekvorm, adelfoi, het by Petrus beslis beklemtonende krag; (ii) dio is ' $\mathrm{n}$ voorsetsel met besondere $\mathrm{krag}$ wat die werklike implikasie van wat vooraf gesê is, inlui; (iii) die toevoeging van mallon tot dio (let wel: sy posisie tussen dio en adelfoi is 'n sterk aanduiding dat mallon saam met dio en nie saam met die werkwoord nie, gelees moet word, dus: „Daarom destemeer") dien as verdere beklemtoning van die erns van die oproep in vers 10 .

Maar wat beteken dit en hó maak 'n gelowige sy „roeping en verkiesing vas"? Die volgende diagramme van die gedagtestruktuur van $2 \mathrm{Pt}$. 1:3-11 behoort baie verhelderend hieroor te werk.

Eers word 'n diagram gegee wat die geheelstruktuur, ontleed met die oog op beantwoording van die vraag HOE en WAARTOE moet ons roeping en verkiesing vas gemaak word:

Sien diagram op bladsy 40.

Vervolgens word 'n uittreksel uit 2 Pt. 1:3-11 gemaak wat klaarblyklik belangrike lig werp vir 'n Skriftuurlik-beoordeelde beskouing oor die moeilike saak van die verhouding tussen menslike verantwoordlikheid en Goddelike roeping en uitverkiesing:

Menslike verantwoordelikheid en Goddelike roeping en uitverkiesing

3. $\delta \iota \alpha \tau \eta s \varepsilon \pi \iota \gamma \nu \omega \sigma \varepsilon \omega s$

(deur die diepe kennis)

HY ROEP

тov $\kappa \alpha \lambda \varepsilon \sigma \alpha v \tau$ os $\eta \mu \alpha s$

(van Hom wat ons GEROEP HET)

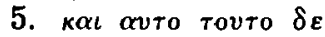

(En juis om hierdie rede)

$\sigma \pi \circ \delta \delta v \pi \alpha \sigma \alpha \nu \pi \alpha \rho \varepsilon เ \sigma \varepsilon v \varepsilon \gamma \kappa \alpha \nu \tau \varepsilon s$

(met die inbreng van ALLE YWER)

JULLE MOET BYVOEG

$\varepsilon \pi \imath \chi \rho \rho \eta \gamma \eta \alpha \tau \varepsilon \ldots$.

(moet julle byvoeg) ....

10. $\delta$ เo $\mu \alpha \lambda \lambda$ ov, $\alpha \delta \varepsilon \lambda \phi \circ \iota, \sigma \pi o v \delta \alpha \sigma \alpha \tau \varepsilon$

(daarom destemeer, broeders, BEYWER

JULLE

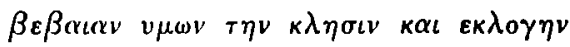

$\pi \mathrm{ol \varepsilon o \vartheta} \alpha \iota$

(om vas temaak julle ROEPING en verkiesing)

JULLE IS GEROEP EN MOET DIT VASMAAK 


\section{Petrus 1:3-11 HOE en WAARTOE word ons ROEPING en VERKIESING vas gemaak}

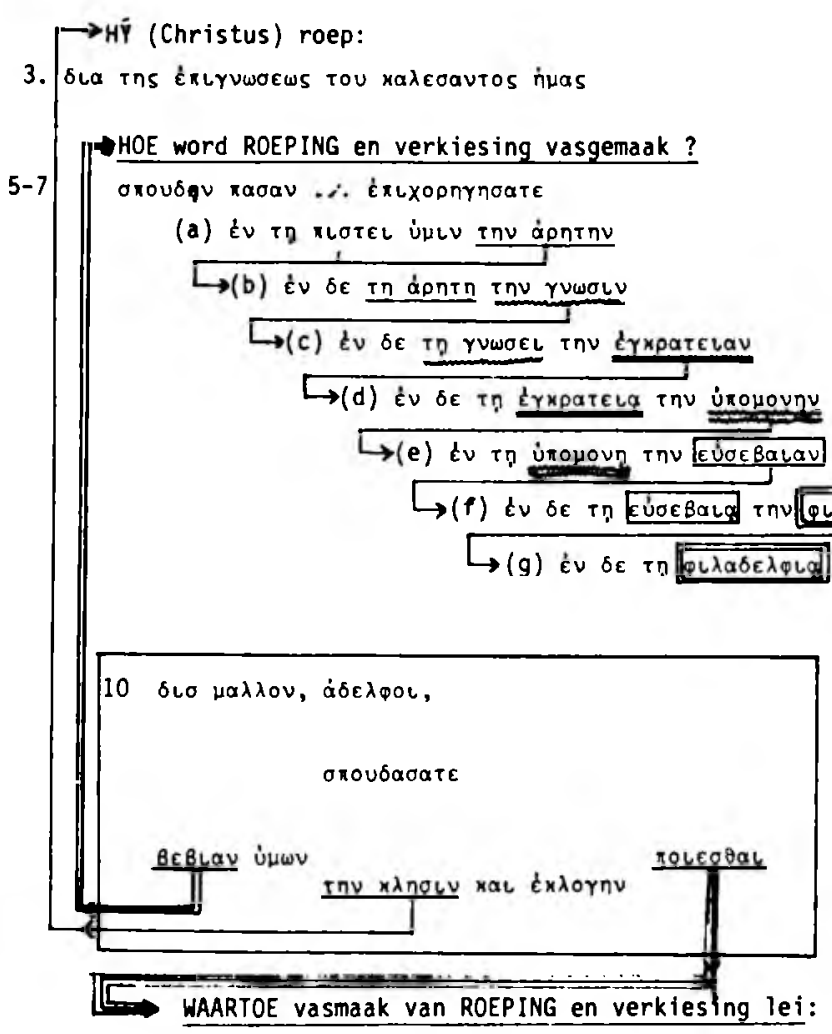

10b-11 tauta Yap rocouvtes,

OUं un rTalonte rote

oútws rap êuxopnynongetal úncv

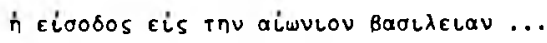

таvта $\gamma \alpha \rho$ TocovvтES

(As julle dié dinge doen)

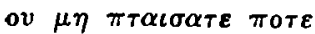

(sal julle nooit struikel nie)

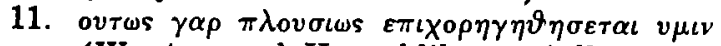

(Want so sal Hy ryklik oor julle

\section{BYVOEG)}

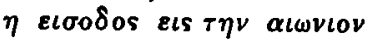

HY SAL BYVOEG

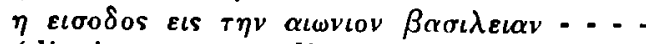

(die ingang van die ewige Koninkryk)

Uit die bostaande ontledings blyk op die minste die volgende:

(i) 2 Pt. $1: 3-11$ is ' $n$ bale hegte en fyngestruktureerde perikoop. Oor wat die woorde van vers $10, \ldots \ldots$ mak julle roeping en ver- 
kiesing vas" beteken, mag dus nie in abstracto, dogmatisties, gespekuleer word nie. Die betekenis MOET vanuit die onmiddellike konteks bepaal word.

(ii) „Roeping", klẽsis, het hier, soos inderdaad gewoonlik elders in die Nuwe Testament, niks te doene met ons "roeping" tot een of ander sending of taak of amp nie. Die klësis of "roeping" van vers 10 sluit aan by die kalesantos, die Roepende Een, van vers 3 . „Roeping" sê in die Nuwe Testament nooit „Gaan - en doen dit of dat..." nie, maar altyd: „Kom - kom na My toe om naby My te mag wees."

(iii) Die „roeping" (klēsis) en die ,verkiesing” (eklogē) lê dus volledig op dieselfde vlak - albei het te doen met God se vrymagtige en in Christus genadige afsondering van sekere mense vanuit die sondige, verlore mensheid. Die eklogë of uitverkiesing lê in die ewigheid, die klēsis of roeping vind hier en nou in die tyd plaas. (iv) Soos die diagram van die geheel perikoop duidelik toon, trek vers 10 al die motiewe in die sentrale boodskap van die hele perikoop saam:

(a) Met tēn klēsin word teruggegryp op vers 3: terwyl God van ewigheid af uitverkies het, roep Hy ons hier in die tyd deur Jesus Christus en die evangelie van "sy heerlikheid en deug."

(b) Die bebaian poiesthai, op „vas maak" van die roeping en verkiesing word nie in vers 10 omskryf nie, maar is juis 'n pregnante manier om onder formule te bring alles wat in vers 5-7 in besonderhede beskryf is?

Hoe maak 'n mens God se ewige uitverkiesing en sy roeping deur Christus hier in die tyd vas?

Deur te ANTWOORD op die roeping: as iemand jou ROEP wil hy dat jy NADERKOM na hom toe. Verse $5-7$ beskryf nie maar algemene, tydlose sogenaamde "Christelike deugde" soos dikwels gekommentariëer word nie. In 'n baie opvallende "trapleerkomposisie" (d.i. die eindbegrip van 'n frase of strofe word die aanvangsbegrip van die nuwe frase of strofe) word die stygende pad waarop die geroepene antwoord op die roeping, beskryf, met as klimakspunt agape - Godomhelsende ware liefde. So maak 'n geroepene sy roeping en verkiesing vas.

(c) Waartoe die vasmaak van die roeping en verkiesing lei word in verse $10 \mathrm{~b}$ en 11 beskryf: in negatiewe sin lei dit daartoe dat só 'n goerepene nooit sal struikel nie; dus nie kán uitval uit die genade nie; in positiewe sin lei dit tot die ryke geskenk (byvoeging) van God om vir ewig te mag ingaan in sy koninkryk - die waarborg van die saligheid.

(v) Die tweede diagram gee 'n beeld van die intieme verband en wonderlike harmonie wat gelê word tussen ons menslike verant woordelikheid en die Goddelike uitverkiesing en roeping: Vers 3 besing die indikatief van God se genadige roeping in en deur Jesus Christus as historiese werklikheid, en verse 5 tot 7 volg dit op met die imperatief om die roeping en verkiesing "vas te maak" deur BYVOEGING van die een stap na die ander van 'n ware nader 
tot God. Vers 10a bring die indikatief van ons geroepe- en verkieswees en die imperatief dat ons dit moet vas maak onder formule, en verse $10 \mathrm{~b}$ en 11 volg dit op met die heerlike belofte van God se BYVOEGING van ons versekerde ingang in sy ewige koninkryk!

\section{SLOTOPMERKING}

Dit word vertrou dat hiermee enkele Skriftuurlike grondstowwe as basis vir verdere gesprek en studie rondom hierdie kernsaak in ons allerheiligste geloof opnuut blootgelê is. 